\title{
In Vivo Imaging of Functional Inhibitory Networks on the Mauthner Cell of Larval Zebrafish
}

\author{
Masaharu Takahashi, ${ }^{1}$ Madoka Narushima, ${ }^{1}$ and Yoichi Oda ${ }^{1,2}$ \\ ${ }^{1}$ Laboratory of Neuroscience, Division of Biophysical Engineering, Graduate School of Engineering Science, \\ Osaka University, and 2Precursory Research for Embryonic Science and Technology, Osaka 560-8531, Japan
}

\begin{abstract}
Noninvasive in vivo calcium imaging was used to observe and characterize inhibitory circuitry in intact larval zebrafish. In the teleost hindbrain, the inhibitory network onto the major pair of reticulospinal neurons known as Mauthner cells (M-cells) has been described in detail. There are three sources of inhibition onto M-cells: recurrent inhibition mediated by an ipsilateral collateral of the M-cell axon, feedforward inhibition driven by sensory afferents, and reciprocal inhibition between bilaterally opposed M-cells. To visualize these inhibitions, M-cells were retrogradely loaded with the calcium indicator calcium green dextran. Recurrent inhibition attenuated the $\mathrm{Ca}^{2+}$ response associated with an action potential in M-cells. Whole-cell recording revealed recurrent IPSCs, the conductance of which may underlie the shunting effect on action potentials and the attenuation of the $\mathrm{Ca}^{2+}$ signal in M-cells. Blocking synaptic transmission within the recurrent network abolished both the
\end{abstract}

$\mathrm{Ca}^{2+}$ signal attenuation and the IPSCs. Electrical stimulation of the otic vesicle to activate VIII nerve afferents resulted in feedforward suppression of antidromically evoked test $\mathrm{Ca}^{2+}$ responses in the contralateral M-cell. Orthodromic activation of $\mathrm{M}$-cells produced a reciprocal reduction of the test $\mathrm{Ca}^{2+}$ response in the contralateral M-cell. Thus, in the present study, we visualized the three types of inhibition and demonstrated that they are functional at $4 \mathrm{~d}$ after fertilization. The use of noninvasive techniques to image inhibition in vivo suggest the plausibility of studying the hypothesis previously tested in adult goldfish that use-dependent changes in inhibitions underlie sound conditioning in escape behavior.

Key words: Mauthner cell; confocal $\mathrm{Ca}^{2+}$ imaging; zebrafish larva; local inhibitory circuits; glycinergic synapse; recurrent IPSCs
Inhibitory networks are crucial for neural processing of sensory information and motor control. Feedback and feedforward inhibition are present in diverse neural structures and are the principal systems for restricting neural activity (Windhorst, 1996). Optical imaging has provided a means for noninvasively studying local circuitry in the intact animal. However, it has not yet been applied to monitor synaptic inhibition in vivo. For resolving neural activity at single-cell resolution in an intact animal, one of the key technical requirements is a high signal-to-noise ratio in the optical signal (Tsien, 1988; Fetcho and O’Malley, 1997; McPherson et al., 1997). With the use of fluorescent $\mathrm{Ca}^{2+}$ indicators, a large optical signal can be obtained from an individual neuron even without signal averaging (Fetcho and O'Malley, 1995; O’Malley et al., 1996; Di Prisco et al., 1997; Svoboda et al., 1997). Callaway et al. (1995) took advantage of the robustness of the optical signal from calcium indicators to monitor synaptic inhibition in vitro. We therefore have applied this approach in vivo, taking advantage of the transparency of the zebrafish, to studying the inhibitory network in zebrafish larva.

Mauthner cells (M-cells), a large pair of reticulospinal neurons,

Received Oct. 18, 2001; revised Feb. 12, 2002; accepted Feb. 22, 2002.

This work was supported by research fellowships of the Japan Society for the Promotion of Science to M.T. and Grants-in-Aid for Scientific Research A-12358013 and 10680743 and Priority Area Grants A-11168216, 11170231, and 12053246 to Y.O. We thank Drs. E. S. Ruthazer, W.-J. Song, N. Yamamoto, F. Murakami, H. Kobayashi, and N. D. Cook for helpful comments. We also thank Y. Murayama for the collaboration in our early electrophysiological study.

Correspondence should be addressed to Yoichi Oda, Neuroscience Laboratories, Graduate School of Frontier Biosciences, Osaka University, Machikaneyama 1-3, Toyonaka, Osaka 560-8531, Japan. E-mail: oda@fbs.osaka-u.ac.jp.

Copyright $\odot 2002$ Society for Neuroscience $0270-6474 / 02 / 223929-10 \$ 15.00 / 0$ are a good model for in vivo inhibitory imaging at single-cell resolution, because they can be clearly identified optically in vivo (O’Malley et al., 1996; Di Prisco et al., 1997), and inhibitory networks onto teleost M-cells have been well documented (Furukawa and Furshpan, 1963; Faber and Korn, 1978; Zottoli and Faber, 1980; Triller and Korn, 1981; Kimmel et al., 1985; Hatta and Korn, 1998). In adult fish, three types of glycinergic inputs, recurrent, reciprocal, and feedforward inhibition, critically control the excitability of the M-cell (Oda et al., 1995, 1998; Hatta and Korn, 1999) (Fig. 1B). The feedforward inhibition from eighth nerve afferents controls the firing threshold of both M-cells. Once one of the paired M-cells is activated, it is immediately inhibited by recurrent inhibition via the collateral pathway. At the same time, the contralateral M-cell is suppressed by reciprocal inhibition. M-cell activity manifests itself in the escape behavior of the animal (Zottoli, 1977; Eaton and Kimmel, 1980; Eaton et al., 1981; Liu and Fetcho, 1999; Zottoli et al., 1999). The direction of the initial turn of the fast escape response ( $\mathrm{C}$ start) is determined by which of the two M-cells is activated. Thus, these three types of inhibitory networks are very important for the proper control of M-cell activation and subsequent escape.

Because the antidromic (AD) spike of the M-cell propagates almost passively from the initial segment to the soma, the inhibitory postsynaptic conductances activated by these pathways exert shunting effects on the AD spikes (Furukawa and Furshpan, 1963; Faber and Korn, 1982; Oda et al., 1995; Hatta and Korn, 1998) (Fig. 1C). To visualize the function of these three types of inhibitory networks in intact zebrafish larvae, we assessed the attenuation of the M-cell optical response associated with the shunting effects on the AD spike. 


\section{MATERIALS AND METHODS}

Retrograde labeling of $M$-cell. Larvae were obtained from a zebrafish (Danio rerio) colony raised at $28.5^{\circ} \mathrm{C}$ and maintained according to established procedures (Westerfield, 1995). All procedures were performed in compliance with the guidelines stipulated by the Osaka University Committee on Animal Research. Four to $8 \mathrm{~d}$ postfertilization (dpf) zebrafish were anesthetized with $0.02 \%$ 3-aminobenzoic acid ethyl ester (MS-222) in chilled $\left(4^{\circ} \mathrm{C}\right) 10 \%$ HBSS and placed on the stage of an upright microscope (Nikon Biophot). HBSS consisted of (in $\mathrm{mM}$ ): $13.7 \mathrm{NaCl}, 0.54$ $\mathrm{KCl}, 0.025 \mathrm{Na}_{2} \mathrm{HPO}_{4}, 0.044 \mathrm{KH}_{2} \mathrm{PO}_{4}, 1.3 \mathrm{CaCl}_{2}, 1.0 \mathrm{MgSO}_{4}$, and 4.2 $\mathrm{NaHCO}_{3}, \mathrm{pH}$ 7.2. To label M-cells retrogradely in intact fish, a solution consisting of $25 \%$ calcium green dextran (CGD, 10,000 molecular weight; Molecular Probes, Eugene, OR) in (in mM): $134 \mathrm{NaCl}, 2.9 \mathrm{KCl}, 2.1$ $\mathrm{CaCl}_{2}, 1.2 \mathrm{MgCl}_{2}, 10 \mathrm{HEPES}$, and 10 glucose, $290 \mathrm{mOsm}, \mathrm{pH}$ 7.8, was pressure-injected via a glass microcapillary into the spinal cord at the 15-somite (anus) level (modified from the method of O'Malley et al., 1996) by using a Picospritzer II (General Valve, Fairfield, NJ). This solution, without CGD, was also used as the bathing solution for brainexposed preparations (see below). After the injection, the fish were maintained in $10 \%$ HBSS $\left(28.5^{\circ} \mathrm{C}\right)$ to recover. An imaging study of M-cell somata was performed 5-24 hr after CGD injection. The transparency of the fish allowed us to see neurons as well as to observe the heartbeat and blood flow to monitor the viability of the fish.

CGD detects relative changes in $\mathrm{Ca}^{2+}$ concentration. We did not use a UV calcium indicator, such as fura-2, suitable for monitoring the absolute value of internal calcium, because too much intrinsic fluorescence in zebrafish larvae would have been excited by UV light.

Calcium imaging with confocal microscopy. All procedures were performed at room temperature $\left(25^{\circ} \mathrm{C}\right)$. Fish anesthetized with $0.01 \% \mathrm{MS}$ 222 were embedded in low-melting point (gelling at $28^{\circ} \mathrm{C}$ ) agarose $(5 \%$; Invitrogen, Gaithersburg, MD) on a recording chamber. After the agarose was congealed, holes were cut in it to permit the introduction of bipolar tungsten electrodes to stimulate the spinal cord and otic vesicle. The preparation was kept in a chamber filled with $10 \%$ HBSS and was placed on a manipulation stage (Narishige, Tokyo, Japan). The zebrafish brain was scanned by a confocal system (FV300; Olympus Optical, Tokyo, Japan) mounted on an Olympus BX50W I upright microscope with a water immersion lens $(40 \times, 0.8$ numerical aperture objective; Olympus). The confocal system was completely isolated from the manipulation stage.

$\mathrm{Ca}^{2+}$ responses at the $\mathrm{M}$-cell were monitored without signal summation either by collecting a sequence of images $(512 \times 512$ pixels $)$ at 260 msec intervals or by scanning a single line through the M-cell soma at 2 msec intervals. To ensure that an increase in the fluorescence of the cell was not a result of its movement to a brighter plane, we focused at the brightest focal plane before each trial.

The spinal cord was stimulated at a position rostral to the site of CGD injection to activate the M-axon. Stimulus currents consisted of bipolar pulses, $80 \mu \mathrm{sec}$ for each polarization applied every $2 \mathrm{~min}$. The test AD stimulus intensity was kept slightly stronger (mean 1.3-fold) than the threshold $(\mathrm{T})$ for a $\mathrm{Ca}^{2+}$ response in the M-cell. To assess the recurrent inhibition of the M-cell, double AD shocks with interpulse intervals ranging from 5 to $500 \mathrm{msec}$ were delivered. To block the recurrent pathway that was mediated by glycinergic and cholinergic synapses, strychnine $(1 \mu \mathrm{g} / \mathrm{g}$ of body weight) or mecamylamine $(2.5 \mu \mathrm{g} / \mathrm{g}$ of body weight) was injected into the tail. To monitor the feedforward inhibition from eighth nerve afferents onto the contralateral M-cell, an electric shock was applied as the conditioning stimulus to the otic vesicle with subthreshold intensity $(<0.8 \mathrm{~T})$ for ipsilateral M-cell firing and paired with a following test AD stimulus at intervals ranging from 0.5 to 100 msec. The intensity of the conditioning stimulus was raised $(<1.2 \mathrm{~T})$ for firing the ipsilateral M-cell orthodromically to investigate the reciprocal inhibition to the contralateral M-cell.

To examine the contribution of voltage-activated calcium channels on the fluorescence response, $\mathrm{CdCl}_{2}(30-100 \mu \mathrm{M}$ final) was added to the extracellular solution, which consisted of (in $\mathrm{mm}$ ): $134 \mathrm{NaCl}, 2.9 \mathrm{KCl}, 2.1$ $\mathrm{CaCl}_{2}, 1.2 \mathrm{MgCl}_{2}, 10 \mathrm{HEPES}$, and 10 glucose, $290 \mathrm{mOsm}, \mathrm{pH} \mathrm{7.8,}$ bubbled with ambient air in the recording chamber. In this experiment, the whole brain was exposed after removing the eyes, otic vesicles, gut, dorsal skin, and notochord but leaving the caudal body intact.

Data analysis. The fluorescence intensity of an M-cell soma at a single horizontal plane was measured (Fluoview version 3.15; Olympus). Decay time constants of the $\mathrm{Ca}^{2+}$ response and the half-recovery time of inhibitory shunts were obtained by single exponential fits and Boltzmann equation fits, respectively, with Origin 3.0 (Microcal). Results are pre- sented as means \pm SEM. The fraction of $\mathrm{Ca}^{2+}$ concentration increase under synaptic inhibition was calculated as $\Delta A / A$, where $A$ or $\Delta A$ represents the peak amplitudes of $\mathrm{Ca}^{2+}$ responses elicited by a single AD shock or that elicited by test AD shock after the conditioning stimulus, respectively.

To show the fluorescence images in the figures, the fluorescence intensity of M-cells was pseudocolored by using the Confocal Assistant 4.02 program (freeware produced by T. C. Brelje).

Whole-cell recordings. Zebrafish larvae of 4-5 dpf were anesthetized with $0.01 \%$ MS-222 and immobilized with D-tubocurarine (3 $\mu \mathrm{g} / \mathrm{g}$ of body weight). The whole brain was exposed after removing rostral structures but leaving the spinal cord intact as described above. The preparation was set in the recording chamber that was continuously perfused with the extracellular solution (see above; Drapeau et al., 1999). Preparations were placed on a stage (Gibraltar; Burleigh) of an upright microscope (BX50WI; Olympus). M-cell somata and the proximal portion of their lateral dendrites were easily identified under an infrared differential interference contrast CCD camera system (C2741; Hamamatsu, Hamamatsu City, Japan) with a water immersion lens for infrared light $(40 \times, 0.8$ numerical aperture; Olympus).

Whole-cell currents were recorded using an Axoclamp 200B amplifier (Axon Instruments), low-pass-filtered at $5 \mathrm{kHz}$, and digitized at $20 \mathrm{kHz}$. Patch-clamp electrodes were filled with (in $\mathrm{mm}$ ): $105.3 \mathrm{~K}$ gluconate, 25 $\mathrm{KCl}, 2 \mathrm{MgCl}_{2}, 10 \mathrm{HEPES}, 10$ EGTA, and $4 \mathrm{Na}_{4} \mathrm{ATP}, 290 \mathrm{mOsm}, \mathrm{pH}$ 7.2. Data were acquired with pClamp 8.0 software and analyzed off-line with Clampfit 8.0 software (Axon Instruments).

After the recording session, the M-cell was labeled by injection of Lucifer yellow (Sigma, St. Louis, MO) from the patch pipette. A confocal image of the M-cell was used for final identification.

\section{RESULTS}

The inhibitory conductances that underlie local inhibition of the M-cell can be studied electrophysiologically by their shunting effect on the AD spike in the soma. The time course of the shunting effect corresponds to that of the inhibitory postsynaptic current on the M-cell (Furukawa and Furshpan, 1963; Faber and Korn, 1982; Oda et al., 1995; Hatta and Korn, 1998) (Fig. 1C). To visualize local inhibition in the intact animal, we retrogradely labeled M-cells in intact larvae with CGD (Fig. 1A1,A2) and performed optical measurements of changes in intracellular $\mathrm{Ca}^{2+}$ concentration without signal averaging. Here we demonstrate that the intracellular $\mathrm{Ca}^{2+}$ change associated with the generation of an action potential in the M-cell is mediated by $\mathrm{Ca}^{2+}$ influx through voltage-activated calcium channels. We have taken advantage of the fact that inhibitory shunting can induce a reduction in this $\mathrm{Ca}^{2+}$ influx to examine optically the synaptic inhibition mediated by each of the three inhibitory pathways.

\section{$\mathrm{Ca}^{2+}$ response of $\mathrm{M}$-cell elicited by spinal cord stimulation}

A pioneering electrophysiological study using extracellular field potential recording in the zebrafish larva showed that an AD action potential in the M-cell could be generated by spinal cord stimulation (Eaton and Farley, 1975). The antidromically driven $\mathrm{Ca}^{2+}$ response can be evoked at a lower stimulation intensity in M-cells than in other reticulospinal projection neurons, because the large diameter of the M-cell axon (Kimmel et al., 1982) gives it the lowest threshold for extracellular stimulation. Fluorescence intensity in CGD-labeled M-cells increased abruptly after an electrical shock applied to the spinal cord (Fig. 2A1). The elevated fluorescence intensity returned slowly to resting levels, with a decay time constant $(\tau)$ of $1.8 \mathrm{sec}$ (Fig. $2 A 2$ ). In 30 fish studied, the peak fluorescence increase and decay time constant were $60.2 \pm 4.1 \%$ and $1.8 \pm 0.1 \mathrm{sec}$, respectively. A consistent increase in the fluorescence intensity was produced in the same cell using a range of suprathreshold stimulus intensities $(<2.5 \mathrm{~T}$, six of six 

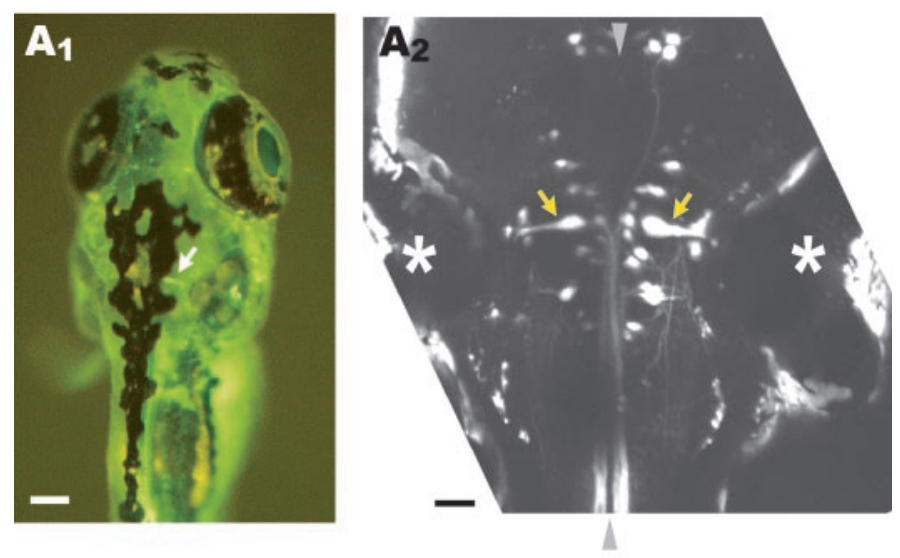

B

C
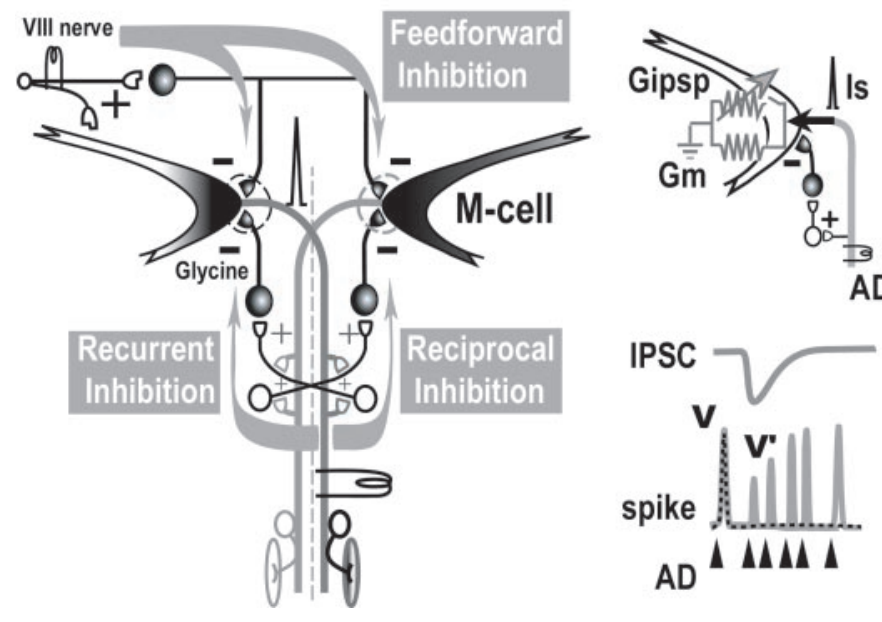

Figure 1. Retrograde labeling of the Mauthner cells. A1, Dorsal view of a living zebrafish at $6 \mathrm{dpf}$ that had been injected in the spinal cord with CGD. An M-cell (arrow) can be observed in the intact fish by fluorescence microscopy. Scale bar, $100 \mu \mathrm{m}$. A2, Projected confocal stack of the array of reticulospinal neurons in horizontal plane in another larva labeled by bilateral injection of CGD into the spinal cord. The pair of M-cells (arrows) are easily identified as the largest neurons with a lateral dendrite and a commissural axon and are located beside the otic vesicle (asterisk). Rostral is at top. Arrowheads represent the midline. Scale bar, $50 \mu \mathrm{m} . B$, The M-cell of an adult zebrafish receives feedback inhibition from the axon collateral as well as feedforward inhibition from eighth nerve afferents. The feedback inhibition consists of recurrent and reciprocal pathways that are mediated by T-reticular neurons (open symbols) and glycinergic interneurons ( filled symbols). Note that T-reticular neurons appear to be homologous to cranial relay neurons in the goldfish and giant fiber neurons in the hatchetfish (Kimmel et al., 1985). $C$, Because the AD action potential of the M-cell propagates almost passively from the initial segment to the soma, the spike amplitudes in the absence $(V)$ or presence $\left(V^{\prime}\right)$ of inhibition are expressed respectively as $V=I_{\mathrm{s}} / G_{\mathrm{m}}$ or $V^{\prime}=I_{\mathrm{s}} /\left(G_{\mathrm{m}}\right.$ $+G_{\text {ipsp }}$ ), where $G_{\mathrm{m}}$ and $G_{\text {ipsp }}$ represent the resting and inhibitory synaptic conductances, respectively, and $I_{\mathrm{s}}$ represents the spike current. Hence, $G_{\text {ipsp }} / G_{\mathrm{m}}$ is estimated from the ratio of $V / V^{\prime}$ (cf. Furukawa and Furshpan, 1963; Faber and Korn, 1982; Oda et al., 1995; Hatta and Korn, 1998).

fish) (Fig. 2B1,B2). As shown in Figure 2B2, the linear regression line for the peak amplitude versus strength of the suprathreshold stimulus was flat $(0.13 \pm 0.14 \% / \mathrm{T}$, six fish $)$. Thus, the fluorescence change is consistent with the AD spike of the M-cell, which occurs in an all-or-nothing manner.

To examine whether the fluorescence elevation was produced by $\mathrm{Ca}^{2+}$ influx through voltage-activated $\mathrm{Ca}^{2+}$ channels, we added cadmium, a $\mathrm{Ca}^{2+}$ channel blocker, to the bathing solution of brain-exposed zebrafish larvae (Fig. $3 A$ ). The fluorescence increase elicited by suprathreshold stimulation was abolished within $10 \mathrm{~min}$ after $30 \mu \mathrm{M}$ cadmium application in 10 of 10 fish (Fig. 3B). It recovered, at least partially, after $30 \mathrm{~min}$ washing with saline in six of eight fish. The effect of cadmium could not be attributed to an artificial shift in the spike threshold of the M-cell, because no fluorescence response was observed in M-cells even when the stimulus intensity was raised to 2.0-4.0T (nine fish). These results indicate that the fluorescence change evoked by AD stimulation reflects the $\mathrm{Ca}^{2+}$ influx through voltage-activated $\mathrm{Ca}^{2+}$ channels.

$\mathrm{Ca}^{2+}$ release from internal stores (Santalova and Moshkov, 1999) is one possible basis for the $\mathrm{Ca}^{2+}$ response. However, application of thapsigargin, an inhibitor of intracellular $\mathrm{Ca}^{2+}$ release, affected neither the peak amplitude $(A)$ nor the decay time constant $(\tau)$ of the $\mathrm{Ca}^{2+}$ response elicited by an AD stimulation (control vs thapsigargin: $A, 67.8 \pm 2.4$ vs $67.7 \pm 5.1 \% ; p>$ $0.5 ; \tau, 1.5 \pm 0.2$ vs $1.7 \pm 0.3 \mathrm{sec} ; p>0.1$; five fish, paired $t$ test). In addition, after subtracting the inferred $\mathrm{Ca}^{2+}$ response that would have been evoked by the first AD spike alone, the decay time constant of the second $\mathrm{AD} \mathrm{Ca}^{2+}$ response was identical to that of the first AD response ( $\tau$ of the first response, $1.8 \pm 0.1 \mathrm{sec}$ vs $\tau$ of the corrected second response, $1.8 \pm 0.1 \mathrm{sec} ; 10$ fish). These observations do not support a contribution of $\mathrm{Ca}^{2+}$ release from internal stores to the $\mathrm{Ca}^{2+}$ response (Sabatini and Regehr, 1995).

\section{Accumulated $\mathrm{Ca}^{2+}$ response elicited by double-shock AD stimuli}

To visualize the effects of recurrent inhibition, double AD shocks were applied with various interpulse intervals to elicit the shunting effect on the second AD spike (Fig. $1 C$ ). Figure $4 A$ illustrates the $\mathrm{Ca}^{2+}$ response obtained by line scanning an $\mathrm{M}$-cell soma every 2 msec. A single shock applied to the spinal cord produced a $\mathrm{Ca}^{2+}$ increase (Fig. 4A, left, $B$, orange). Double AD shocks at $200 \mathrm{msec}$ (Fig. 4A, right, $B$, red) but not at $5 \mathrm{msec}$ (Fig. 4B, green) intervals caused a further $\mathrm{Ca}^{2+}$ increase. The absence of an additional $\mathrm{Ca}^{2+}$ increase at the $5 \mathrm{msec}$ interstimulus interval could be attributable to the shunting effects on the second spike (Fig. 4C). The line scanning method is adequate to assess the $\mathrm{Ca}^{2+}$ response with high temporal resolution but does not provide a sufficiently high signal-to-noise ratio to quantify the degree of $\mathrm{Ca}^{2+}$ increase without averaging the signal. Two-dimensional scanning of a restricted area of the M-cell soma used in the present study produces a much higher signal-to-noise ratio. Its temporal resolution was also sufficient to monitor the time course of the shunting effect. Thus, the area of the M-cell soma was scanned to assess the time course of the inhibitory effect quantitatively.

The peak amplitude of the $\mathrm{Ca}^{2+}$ response reveals the integrated $\mathrm{Ca}^{2+}$ influx elicited by double AD shocks. As shown in Figures $5 B 2$ and $6 A$, double $\mathrm{AD}$ shocks with interstimulus intervals of 50-500 msec produced much larger $\mathrm{Ca}^{2+}$ elevations than those evoked by a single shock (Figs. 5A, 6A). In contrast, for intervals of 5-30 msec, only a fractional or no increase above the single-shock control response was observed (Figs. 5B1, 6A). Similar inhibition in $\mathrm{Ca}^{2+}$ responses was observed in zebrafish aged from 4 to $8 \mathrm{dpf}$ (Table 1 ). Figure $6 B$ shows the summarized time course of the attenuation in $\mathrm{Ca}^{2+}$ elevation elicited by double AD shocks (11 fish). It indicates the time course of recurrent inhibition elicited by the first AD stimulus. 
Figure 2. Fluorescence increase elicited in M-cell by antidromic stimulation. A1, Transient fluorescence increase was observed after an electrical shock was applied to the spinal cord (asterisk). The time (seconds) before and after the stimulus is denoted in each frame. The color scale on the left represents fluorescence intensity (blue, lowest; red, highest). Scale bar, $20 \mu \mathrm{m}$. $A 2$, The fluorescence intensity of somata, the yellow region of interest of the last panel in A1, exhibited an abrupt increase and slow decay with a time constant of $1.8 \mathrm{sec}$ (red dotted line, single-exponential fit). Increase in fluorescence $(\Delta F)$ was normalized by the resting level $(F)$. B1, Transient fluorescence changes in a M-cell induced by several different intensities of spinal cord shock (arrowhead) were superimposed. The stimulus strength was expressed as a fraction of the M-cell firing threshold (T). B2, Relationship between peak fluorescence increase $(\Delta F / F ; y$-axis $)$ and stimulus intensity ( $x$-axis) in the M-cell as exemplified in B1. The fluorescence increase induced by suprathreshold stimulus $(<2.5 \mathrm{~T})$ was constant (solid line represents a linear regression line). Thus, the $\mathrm{Ca}^{2+}$ response appeared in an all-ornone manner, like antidromic M-cell spike generation.
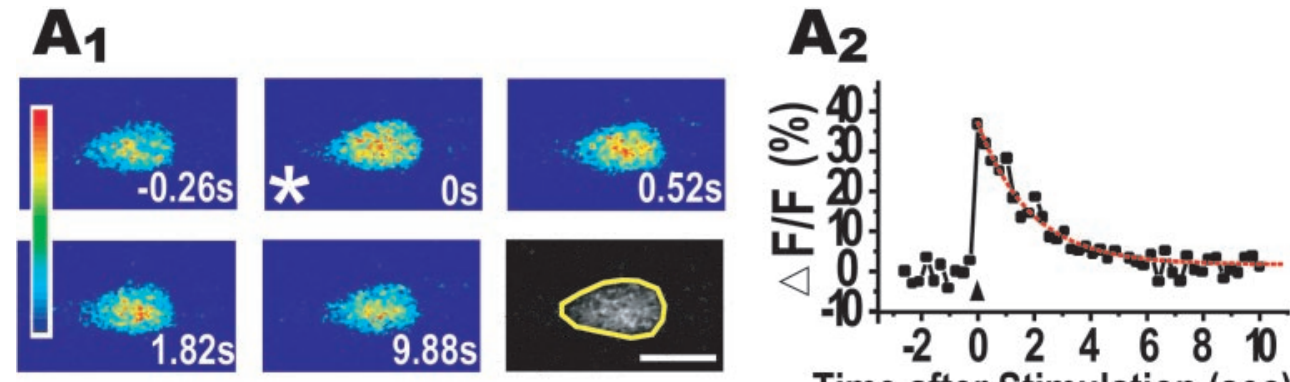

Time after Stimulation (sec)

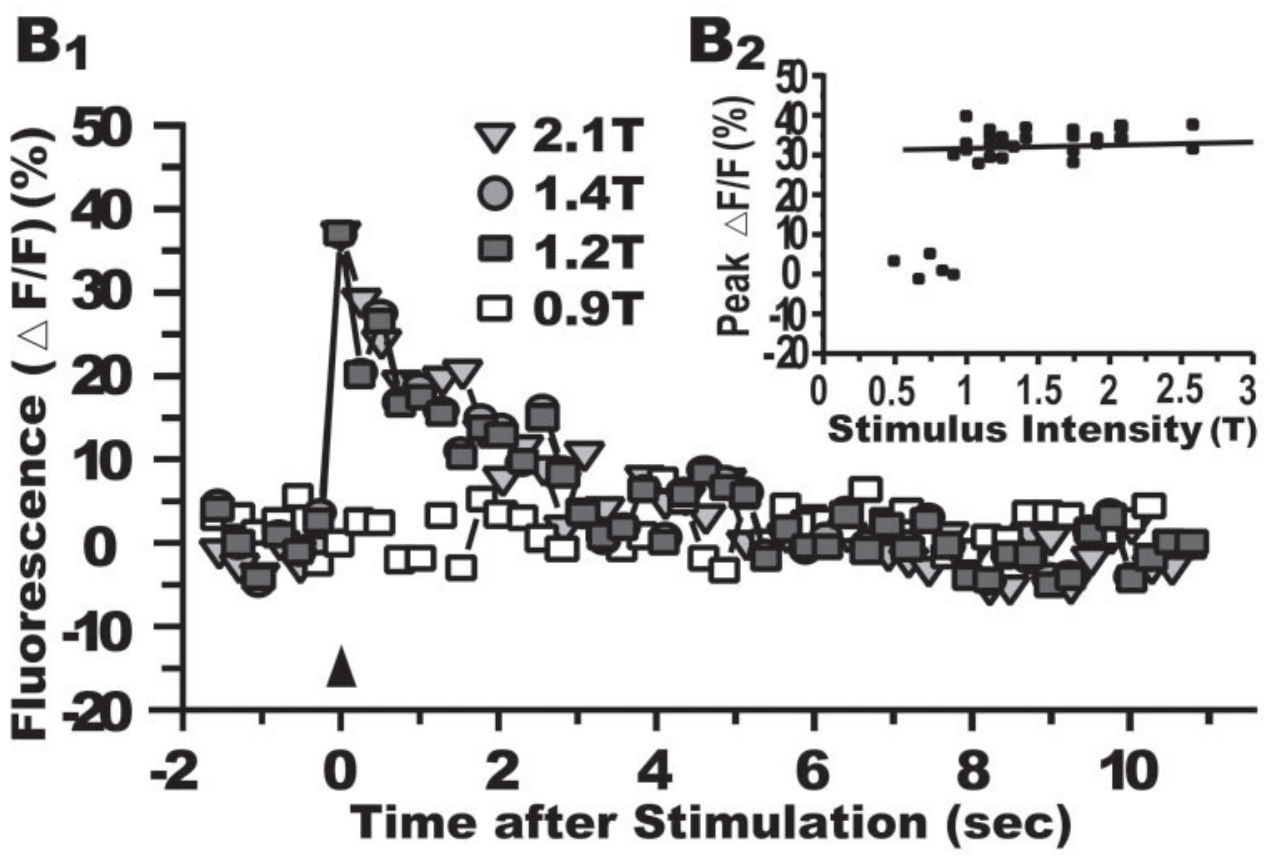

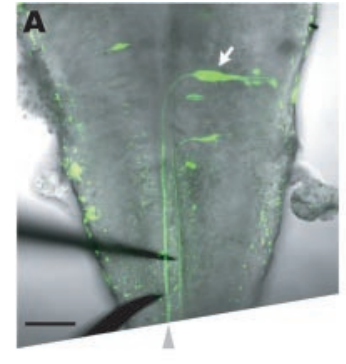

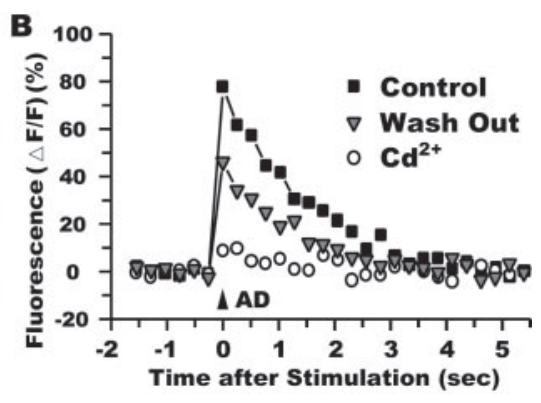

Figure 3. The fluorescence change mediated by voltage-activated $\mathrm{Ca}^{2+}$ channels. $A$, Ventral view of an exposed brain of a zebrafish larva (see Materials and Methods). A fluorescent image of retrograde labeling of a left M-cell (arrow) and a transmitted light image were merged. Bipolar stimulus electrodes (bottom left) were inserted into the caudal hindbrain and positioned near the M-axon (arrowhead). Rostral is at the top. Scale bar, $50 \mu \mathrm{m}$. B, The fluorescence increase (square) in response to stimulation of the M-axon was almost completely abolished (circle) within $10 \mathrm{~min}$ by bathing with cadmium (30 $\mu \mathrm{M}$ )-containing solution. The response partially recovered (triangle) after 46 min washout. Stimulus intensity was $1.2 \mathrm{~T}$ in control and washout but $2.5 \mathrm{~T}$ during cadmium application.

\section{Blocking the recurrent inhibitory pathway diminished the attenuation}

To confirm that the attenuation of the $\mathrm{Ca}^{2+}$ response was attributable to recurrent inhibition, we examined the effects of blocking synaptic transmission pharmacologically on the $\mathrm{Ca}^{2+}$ response in one of the following ways. First, we applied strychnine, a glycine receptor blocker, to remove the synaptic inhibition onto the M-cell, because the inhibitory interneurons in the recurrent pathway are mainly glycinergic (Furukawa et al., 1964). Second, we applied mecamylamine, a nicotinic acetylcholine receptor blocker, to block the synaptic transmission between the M-axon and the T-reticular neurons, because the $\mathrm{M}$-cells are thought to be cholinergic $(\mathrm{Fu}-$ rukawa et al., 1964; Day et al., 1983; Waldeck et al., 2000). The attenuation of the $\mathrm{Ca}^{2+}$ response almost disappeared after injection of strychnine or mecamylamine into the tail (Fig. 7A,B). Under these conditions, the $\mathrm{Ca}^{2+}$ responses elicited by paired $\mathrm{AD}$ shocks at $5 \mathrm{msec}$ intervals were comparable with those at $50-500 \mathrm{msec}$. Summarized data (Fig. $7 C$ ) show that $\Delta A / A$ values at an interstimulus interval of $5 \mathrm{msec}$ under strychnine (55.4 \pm $7.7 \%$; 8 fish $)$ or mecamylamine $(48.9 \pm 6.9 \%$; 11 fish $)$ were significantly larger $(p<0.0001, t$ test $)$ than that in control fish $\left(5.8 \pm 1.6 \% ; 25\right.$ fish). Thus, the inhibitory shunt of the $\mathrm{Ca}^{2+}$ response evoked by double shocks is mediated by the recurrent inhibition of the M-cell.

Under both normal and mecamylamine-blocked conditions, the $\mathrm{Ca}^{2+}$ response evoked by double shocks at a $2 \mathrm{msec}$ interval exhibited a small increase (examined in three fish) from the response evoked by a single AD pulse (Fig. $7 B$ ), suggesting that the second $\mathrm{AD}$ spike was partially blocked at the interval of 2 msec by refractoriness of the membrane. 


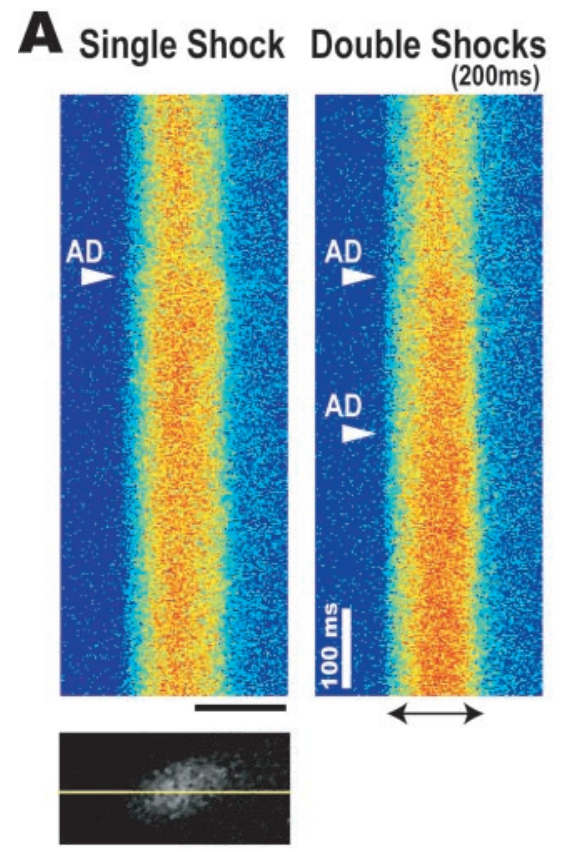

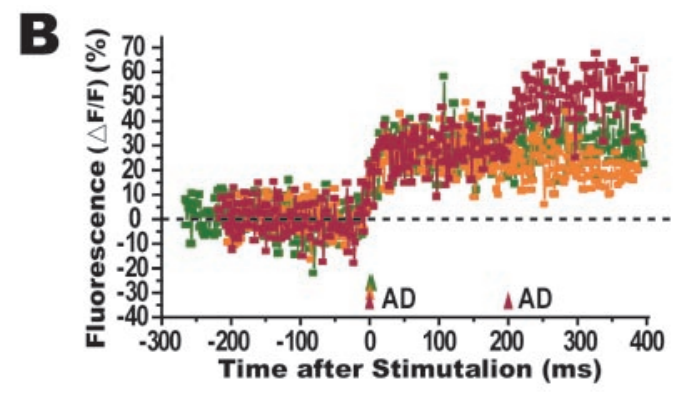

Paired spikes without inhibitory shunt Shunt of the 2nd spike

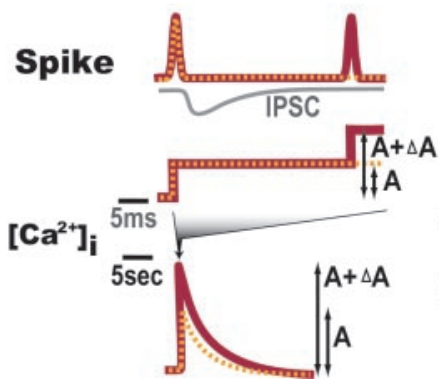

Figure 4. Shunt of $\mathrm{Ca}^{2+}$ increase in an M-cell. $A$, An M-cell soma was scanned by a line (yellow line in bottom panel) that passed through the M-cell soma. The fluorescence of the line acquired repeatedly every $2 \mathrm{msec}$ is displayed from top to bottom. Fast $\mathrm{Ca}^{2+}$ elevation was evoked after AD shocks (arrowhead). The $\mathrm{Ca}^{2+}$ increase elicited by double shocks with an interval of $200 \mathrm{msec}$ (right) was larger than the response evoked by a single shock (left). Scale bar, $20 \mu \mathrm{m}$; calibration, 100 msec. B, Approximately $30 \%$ of the $\mathrm{Ca}^{2+}$ increase was elicited by a suprathreshold single AD shock (orange). Additional $\mathrm{Ca}^{2+}$ elevation to $\sim 50 \%$ was observed when the second $\mathrm{AD}$ stimulation was applied $200 \mathrm{msec}$ later (red). In contrast, no additional elevation was induced with $5 \mathrm{msec}$ interval (green). Every point represents the fluorescence of the soma. Baselines of resting fluorescence levels are represented by the dotted line. $C$, An AD spike of an M-cell induces the recurrent IPSC with large synaptic conductance. Left, When the second AD spike is evoked after the IPSC is completed, the spike is not shunted, and additional $\mathrm{Ca}^{2+}$ elevation $(\Delta A)$ is observed. Right, When a second AD spike is evoked during an IPSC, the spike amplitude is shunted, and the second Ca ${ }^{2+}$ elevation is reduced.

\section{A Single Shock}
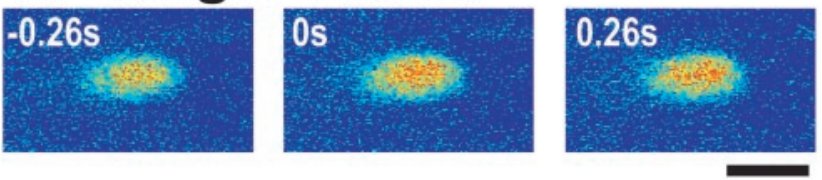

\section{\begin{tabular}{l} 
B1 Double \\
$-0.26 \mathrm{~s}$ \\
\hline
\end{tabular}}
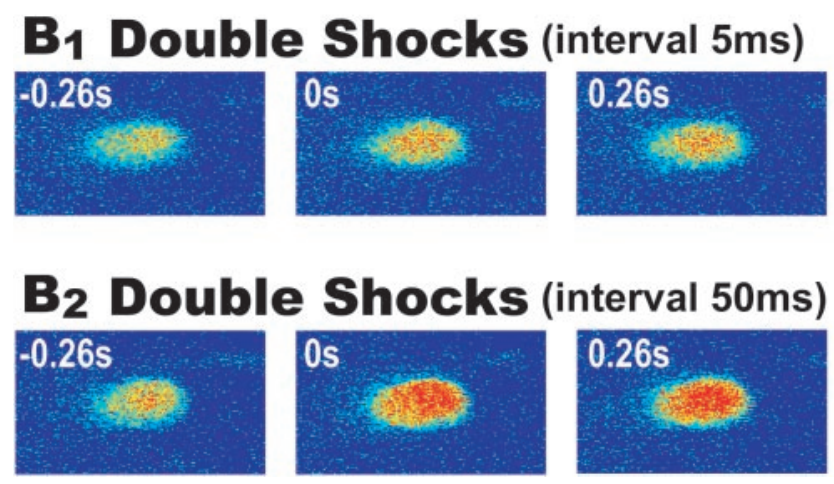

Figure 5. $\mathrm{Ca}^{2+}$ elevation in an M-cell in response to single $(A)$ or double $(B 1, B 2)$ AD shocks. The time (seconds) before and after the stimulus is denoted in each frame. The color scale on the right is the same as in Figure 2. A single shock $(A)$ and double $\mathrm{AD}$ shocks with a $5 \mathrm{msec}$ interval $(B 1)$ produced similar levels of $\mathrm{Ca}^{2+}$ increase. In contrast, the double shocks with a $50 \mathrm{msec}$ interval evoked a much larger $\mathrm{Ca}^{2+}$ increase. Scale bar, $20 \mu \mathrm{m}$.

\section{Whole-cell recordings of recurrent IPSC}

To confirm that the inhibition induced by AD stimulation of the M-cell occurred via the recurrent pathway, we performed whole-cell recordings from larval M-cells. Because the chloride equilibrium potential was adjusted to $-40 \mathrm{mV}$, IPSCs would appear as inward currents at the holding potential of $-70 \mathrm{mV}$, as exemplified in Figure 8. After a spike evoked by a brief depolarization of the M-cell, postsynaptic inward currents were observed. The inward currents and the spiking of the
Table 1. $\mathrm{Ca}^{2+}$ increase reduced by recurrent inhibition

\begin{tabular}{lllll} 
& $4 \mathrm{dpf}$ & $5 \mathrm{dpf}$ & $6 \mathrm{dpf}$ & $8 \mathrm{dpf}$ \\
\hline$\Delta A / A(\%)$ & $11.0 \pm 4.5$ & $3.7 \pm 2.4$ & $1.1 \pm 3.9$ & $6.8 \pm 1.1$ \\
Number & & & &
\end{tabular}

of fish

6

7

5

7

As shown in Figure $4 C$, the fractional increase $(\Delta A / A)$ in peak $\mathrm{Ca}^{2+}$ response with double AD shocks at a $5 \mathrm{msec}$ interval above a single shock was compared between 4 and 8 dpf. No significant change by age was observed ( $p>0.2$; ANOVA).

M-cell occurred coincidentally and in an all-or-nothing manner (Fig. 8A). The inward currents started $2.9 \pm 0.1 \mathrm{msec}$ after the M-cell spike and reached their peak at $2.5 \pm 0.1 \mathrm{msec}$ from the onset with a half-width of $6.9 \pm 0.5 \mathrm{msec}$ (six fish). The inward currents were eliminated by $1 \mu \mathrm{M}$ strychnine (four of four fish) and recovered in three of four fish after washout (Fig. $8 B$ ). Thus, the inward currents represented the recurrent IPSCs of the M-cell mediated by glycinergic synapses. The shape of IPSCs suggested the kinetics of the synaptic conductance underlying them. These results support the idea that the reduction in $\mathrm{Ca}^{2+}$ response as observed above (Figs. 4-6) is attributable to the inhibitory shunt resulting from recurrently activated glycinergic inputs onto the M-cell.

\section{Visualization of feedforward inhibition from sensory afferent to M-cell}

To visualize the feedforward inhibition onto the contralateral M-cell resulting from stimulation of eighth nerve afferents, afferent stimulation and $\mathrm{AD}$ stimulation were applied together. The otic vesicle in zebrafish larvae (4-5 dpf) was electrically stimulated as the conditioning stimulus to activate eighth nerve afferents at an intensity below threshold for firing the ipsilateral M-cell (Fig. 9A). No apparent $\mathrm{Ca}^{2+}$ response was observed in either the ipsilateral or contralateral M-cells in response to this stimulus. 


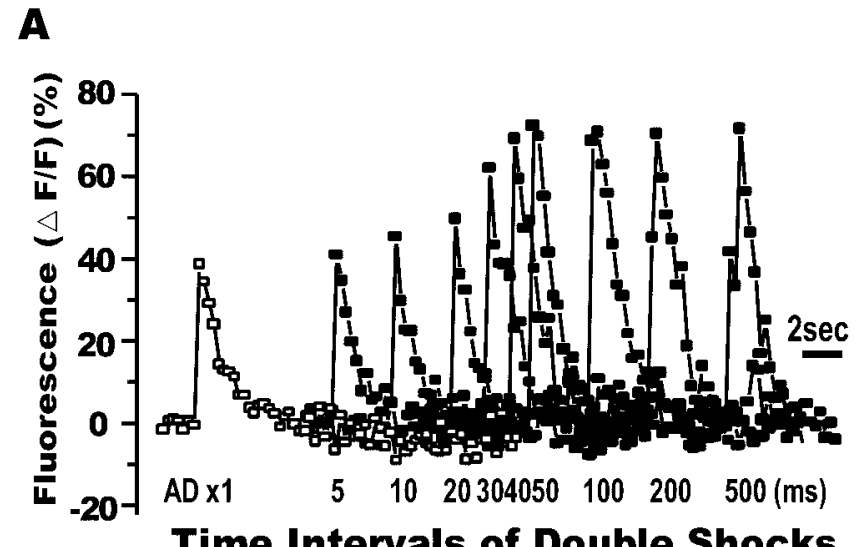

B

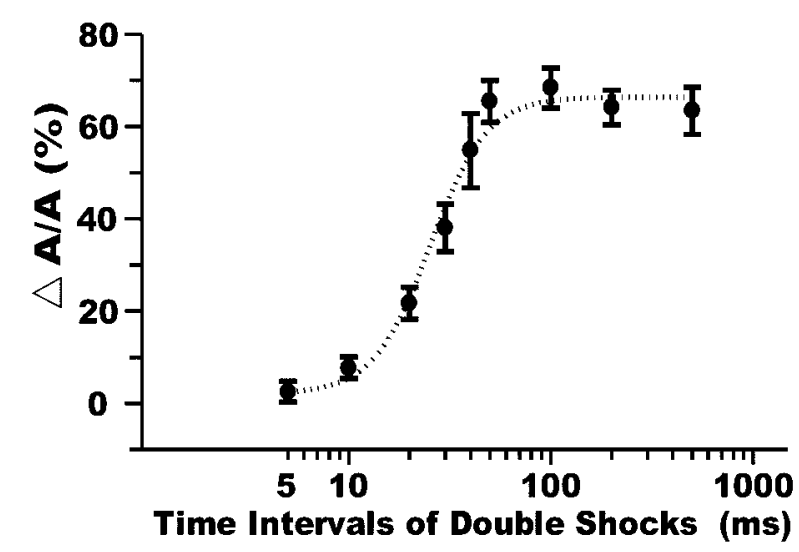

Figure 6. Time course of the inhibitory shunt of an M-cell. A, Superimposed traces of the $\mathrm{Ca}^{2+}$ responses ( filled squares) evoked in an M-cell by double AD shocks spaced at the intervals denoted below. The peak $\mathrm{Ca}^{2+}$ response elicited by double $\mathrm{AD}$ shocks was attenuated when the interval was $<50 \mathrm{msec}$. Note that the peak amplitude for an interval of $5 \mathrm{msec}$ was quite similar to that evoked by a single pulse $(A D \times 1$, open squares $)$. A notch was observed in the rising phase of the $\mathrm{Ca}^{2+}$ response at an interval of $500 \mathrm{msec}$, because the second $\mathrm{Ca}^{2+}$ elevation was combined with the decay phase of the first response, as shown in Fig. $4 B$. B, Relationship between the ratio of an additional increase of $\mathrm{Ca}^{2+}$ response $(\Delta A)$ evoked by the second pulse and that by a single pulse ( $A, y$-axis) and intervals of double pulses ( $x$-axis, in log scale) summarized from 11 fish. The dotted line expresses the Boltzmann fit to the data. The half-recovery time was $25.3 \pm 2.5 \mathrm{msec}$. The effective periods of the inhibitory shunt resemble those obtained in previous electrophysiological studies (cf. Furukawa and Furshpan, 1963; Faber and Korn, 1982; Oda et al., 1995, 1998; Hatta and Korn, 1998).

When a test AD stimulus was paired at intervals of 2-20 msec with the preceding conditioning stimulus, the test $\mathrm{Ca}^{2+}$ response was clearly reduced in amplitude (Fig. 9B). A maximal reduction occurred $2 \mathrm{msec}$ after the onset of the conditioning stimulus. Less reduction was observed for longer intervals. No attenuation of the $\mathrm{Ca}^{2+}$ response was observed for intervals of $\leqq 1 \mathrm{msec}(p>0.1$, ANOVA), suggesting that the feedforward inhibition starts between 1 and $2 \mathrm{msec}$ after the stimulus. As summarized in Figure $9 C$, the normalized amplitude of the $\mathrm{Ca}^{2+}$ response $(\Delta A / A)$ was maximally inhibited at an interval of $2 \mathrm{msec}(\Delta A / A=52.4 \pm$ $6.1 \%$ ) and then gradually recovered to control levels with longer intervals. Thus, the feedforward inhibitory input from eighth
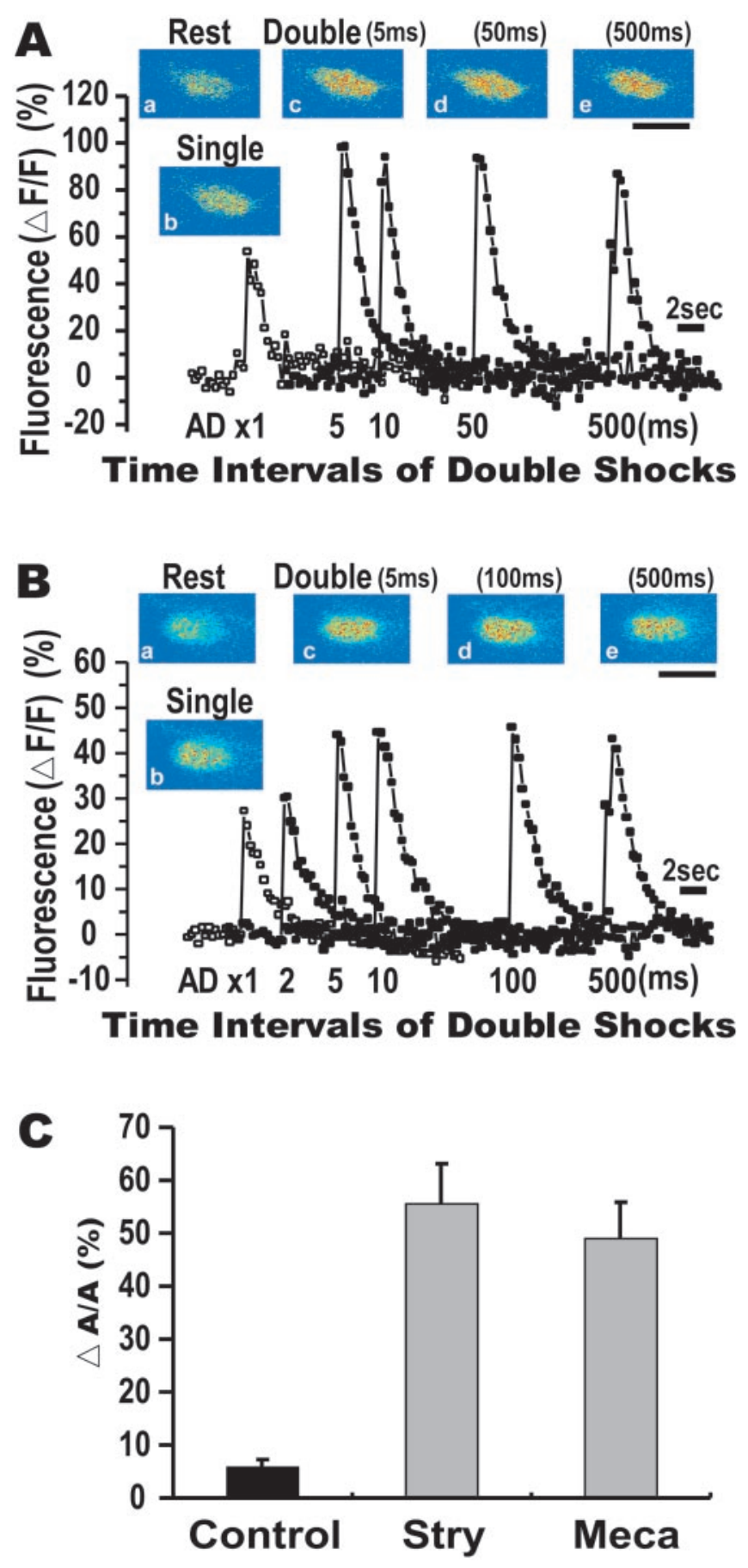

Figure 7. Effects of blocking a recurrent inhibitory pathway. A, The inhibitory shunt of the $\mathrm{Ca}^{2+}$ response was totally eliminated after the glycinergic receptor blocker strychnine was injected to the tail of the intact zebrafish. $\mathrm{Ca}^{2+}$ responses were superimposed as in Figure $6 \mathrm{~A} . \mathrm{Ca}^{2+}$ elevation in response to double AD shocks with a $5 \mathrm{msec}$ interval was not reduced and resembled those obtained at intervals of 10-500 msec. Insets, Pseudocolor images of fluorescence intensity at rest $(a)$ and after single shock $(b)$ and double shocks at intervals of $5(c), 50(d)$, or $500(e)$ msec. $B$, The inhibitory shunting of $\mathrm{Ca}^{2+}$ response was lost by injecting the nicotinic acetylcholine receptor blocker mecamylamine into the tail. $\mathrm{Ca}^{2+}$ increases in response to double shocks with intervals of 5-500 msec were constant. Insets, Pseudocolor images as denoted as in $A$. $C, \Delta A / A$ for the double AD shocks at interval of $5 \mathrm{msec}$ in control and strychnine- and mecamylamine-injected fish. The inhibitory shunt $(\Delta A / A, 5.8 \pm 1.6 \% ; 25$ fish; control) was significantly reduced in strychnine $(\Delta A / A, 55.4 \pm 7.7 \% ; 8$ fish; $p<0.0001, t$ test $)$ or mecamylamine $(\Delta A / A, 48.9 \pm 6.9 \%$; 11 fish; $p<$ $0.0001, t$ test). 


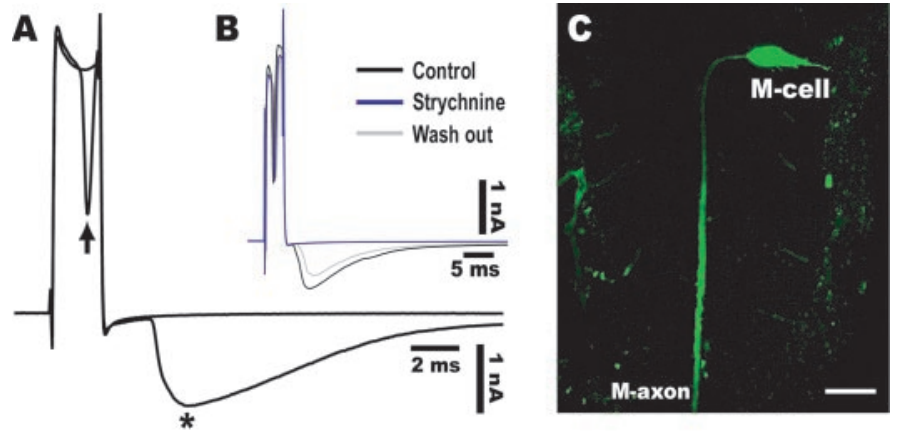

Figure 8. Recurrent inhibitory postsynaptic currents of M-cell. $A$, IPSCs were monitored by whole-cell recording with a KCl-filled patch electrode $\left(E_{\mathrm{Cl}},-40 \mathrm{mV}\right)$ from an M-cell of a $4 \mathrm{dpf}$ zebrafish. Each trace was averaged from seven responses. Recurrent IPSCs (asterisk) were elicited in an all-or-nothing manner associated with the preceding spike of the M-cell (arrow) evoked by brief depolarization (to $+20 \mathrm{mV}$ ). The holding potential was $-70 \mathrm{mV}$. Input resistance was $23 \mathrm{M} \Omega$. $B$, Recurrent IPSCs (black) were completely abolished (blue) within $30 \mathrm{~min}$ by bathing with strychnine $(1 \mu \mathrm{M})$-containing solution. The currents recovered (gray) after 23 min washout. $C$, Confocal fluorescence image of another M-cell after injecting Lucifer yellow from the recording patch pipette. The lateral dendrite and soma of the cell were clearly observed, with the thick axon descending through the contralateral side of medulla. Scale bar, $50 \mu \mathrm{m}$.

nerve afferents to the M-cell could be monitored optically in larval zebrafish.

\section{Reciprocal inhibition to the contralateral M-cell}

Next we assessed the reciprocal inhibition between the two M-cells. Suprathreshold stimulation of the otic vesicle in larval zebrafish (4-5 dpf) caused an apparent $\mathrm{Ca}^{2+}$ increase in the ipsilateral but not in the contralateral M-cell (Fig. 10A). When a test AD stimulus was paired with the suprathreshold conditioning stimulus at intervals of 2-10 msec, the test $\mathrm{Ca}^{2+}$ response was completely abolished (Fig. 10B). It gradually recovered within 50 msec. The larger shunt of the $\mathrm{Ca}^{2+}$ response reflects the reciprocal inhibitory effect between the M-cells in addition to the commissural feedforward inhibition (Fig. 9), because the additional powerful shunt appeared synchronously with the firing of the ipsilateral M-cell. Because the test $\mathrm{Ca}^{2+}$ influx is mediated by voltage-activated $\mathrm{Ca}^{2+}$ channels (Fig. 3), the complete optical shunt could be explained by its sigmoidal current-voltage relationship (Fox et al., 1987). Figure 10C summarizes the time course of the inhibitory shunt elicited by the paired shocks (six fish). $\Delta A / A$ was attenuated at intervals of 2-30 msec compared with control AD test shocks. The onset of inhibition was between 1 and $2 \mathrm{msec}$ after the conditioning stimulus.

In this experiment, the conditioning stimuli were applied at a very low frequency $(0.01 \mathrm{~Hz})$. It has been shown in the adult goldfish that use-dependent synaptic depression at the axoaxonic connection between the M-cell and the cranial relay neuron, which appears to be homologous to the T-reticular neuron in the zebrafish (Kimmel et al., 1985), is induced at higher frequencies (Waldeck et al., 2000). To quantify the activity-dependent depression of the combined (reciprocal and feedforward) inhibition in the present preparation, a paired pulse conditioning paradigm was used. The test $\mathrm{AD}$ response was evoked $5 \mathrm{msec}$ after the second pulse of the conditioning paired stimuli with interpulse intervals ranging from 100 to $3000 \mathrm{msec}$. The inhibitory effect of the second conditioned stimulus could be observed when the
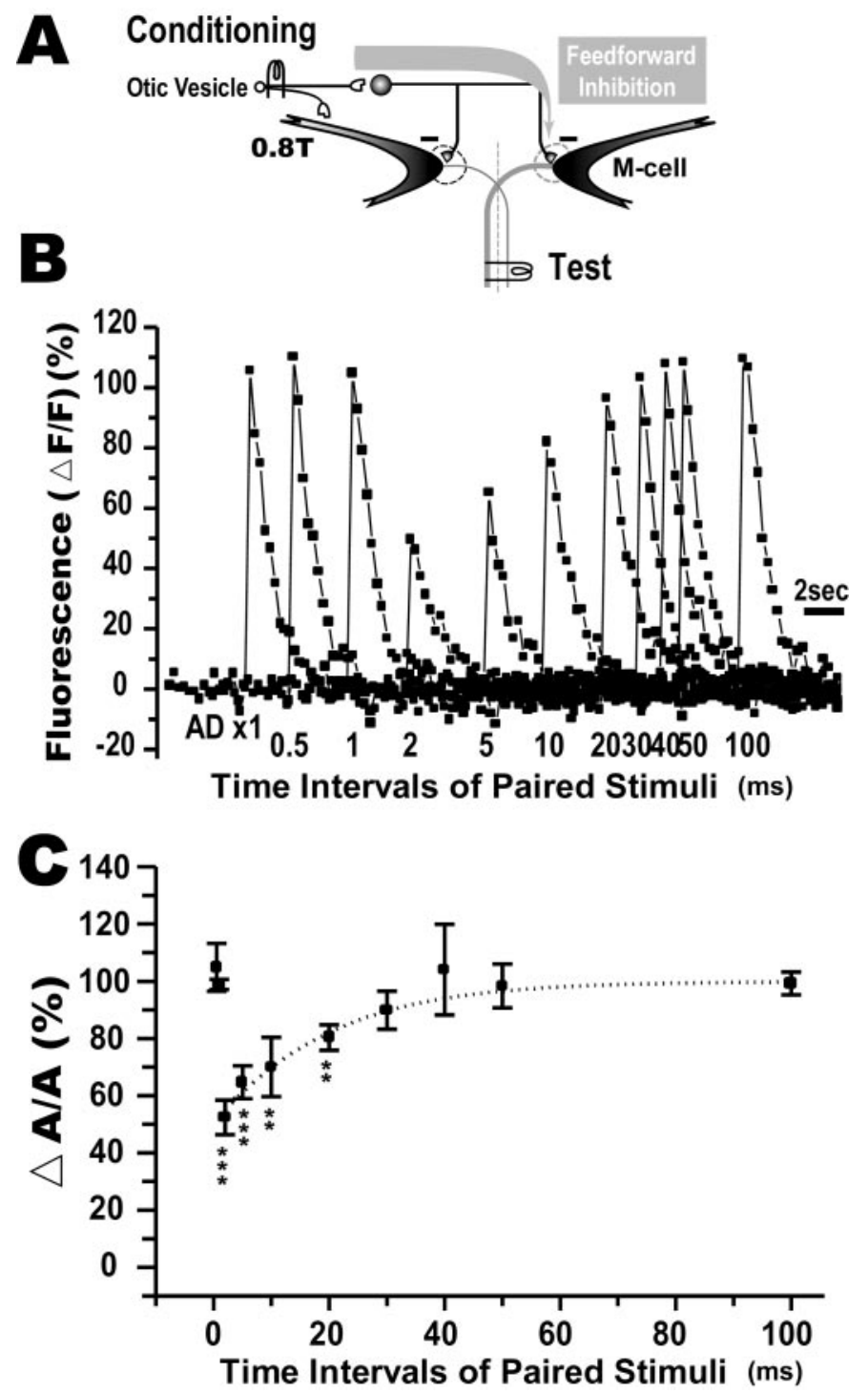

Figure 9. Feedforward inhibition from eighth nerve afferents to the contralateral M-cell. $A$, An otic vesicle was electrically stimulated with subthreshold intensity $(0.8 \mathrm{~T})$ for the ipsilateral M-cell. $B$, Superimposed $\mathrm{Ca}^{2+}$ responses evoked in an $\mathrm{M}$-cell by pairing the afferent and AD stimuli at intervals denoted below. The $\mathrm{Ca}^{2+}$ response was maximally reduced when the two stimuli were paired at a 2 msec interval. $A D \times 1, \mathrm{Ca}^{2+}$ response to the $\mathrm{AD}$ stimulus alone. $C$, Relationship between normalized amplitude of the paired response ( $\Delta A / A, y$-axis) and intervals of the paired stimuli ( $x$-axis), summarized from five fish. $\Delta A / A$ at intervals of $2-20 \mathrm{msec}$ were significantly reduced from control $\left({ }^{* *} p<0.0005 ; * * p<0.002, t\right.$ test). The dotted line expresses the Boltzmann fit to the data points from 2 to $100 \mathrm{msec}$. The half-recovery time was $15.0 \pm 2.6 \mathrm{msec}(n=5)$. The time course of the feedforward inhibitory shunt matches that obtained in a previous electrophysiological study (cf. Oda et al., 1998).

interval of the paired pulse was $>200$ msec but was obviously weakened with a $100 \mathrm{msec}$ interval (Fig. 10D,E). We consider that the remaining optical inhibition reflects the feedforward effect. Together, the use-dependent depression of the reciprocal inhibition was also detectable by the optical approach.

\section{DISCUSSION}

The present work is the first attempt to visualize synaptic inhibition on identifiable neurons in the CNS in an intact vertebrate. 
A
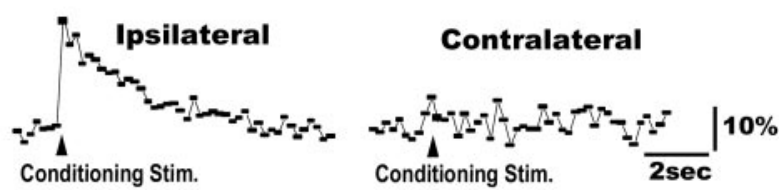

B

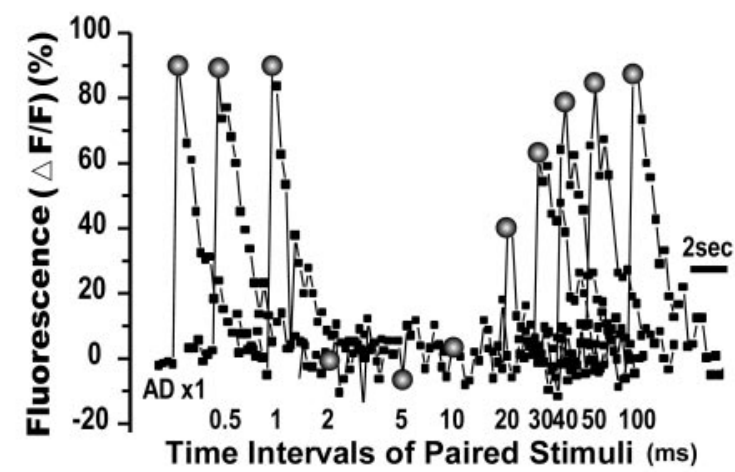

C

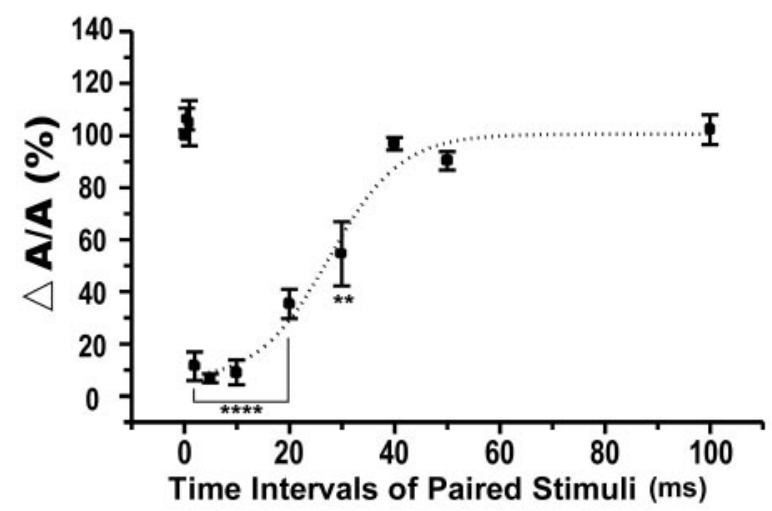

D

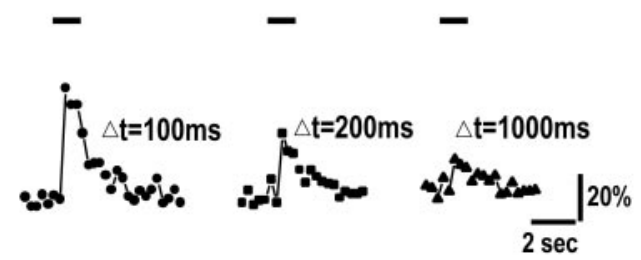

E

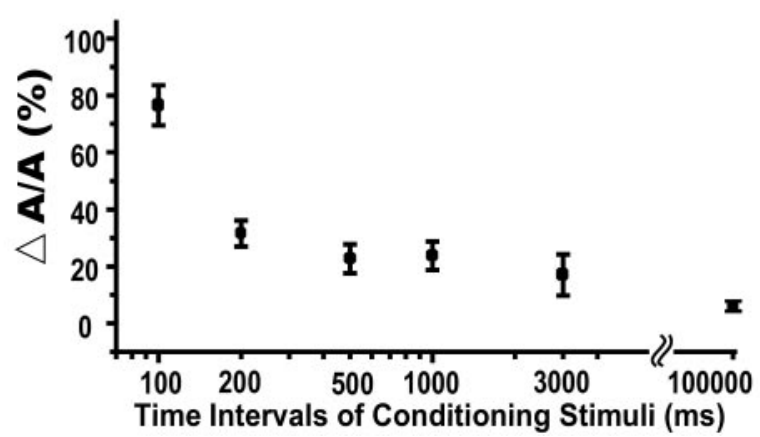

Figure 10. Combination of reciprocal and feedforward inhibitions onto the M-cell. A, A suprathreshold stimulus (1.2T) applied to the otic vesicle to drive ipsilateral M-cell firing elicited an apparent $\mathrm{Ca}^{2+}$ increase in the ipsilateral (left), but not the contralateral (right) M-cell. The arrowhead shows the onset of the otic vesicle stimulus (conditioning stim.). The longer
We have visualized the recurrent, feedforward, and reciprocal forms of inhibition on the M-cell by examining the shunting of $\mathrm{Ca}^{2+}$ responses in the intact zebrafish larvae. With this optical approach, it is evident that all three types of inhibitory networks onto the M-cell are already functional in early larval zebrafish.

\section{Attenuation of the $\mathrm{Ca}^{2+}$ response reveals recurrent inhibition}

The maximum optical shunt associated with recurrent inhibition was observed at an interval of $5 \mathrm{msec}$ (Fig. 6). This attenuation is likely to reflect real recurrent inhibition, because the inhibitory shunt of the $\mathrm{Ca}^{2+}$ response at an interval of $5 \mathrm{msec}$ was dramatically abolished when the recurrent pathway was blocked (Fig. 7). On the contrary, attenuation was still observed at the $2 \mathrm{msec}$ intervals both under normal conditions (11 fish; data not shown) and under blockade of synaptic transmission in the recurrent circuit (Fig. 7B). This probably reflects refractoriness of the M-axon after the first AD spike, as suggested by whole-cell recording, which indicated that the onset of the recurrent IPSCs of the M-cell was 2.5-3.0 msec after the spike (Fig. 8). In addition, axonal refractoriness at a $2 \mathrm{msec}$ interspike interval has been reported previously (Furukawa and Furshpan, 1963). The effects of refractoriness on the $\mathrm{Ca}^{2+}$ response at intervals over $5 \mathrm{msec}$ are negligible in comparison with the recurrent inhibitory conductance (Fig. 7). A previous electrophysiological study in adult goldfish demonstrated that the attenuation of the spike at an interval of $6 \mathrm{msec}$ was only $\sim 7 \%$ when the recurrent inhibition was blocked (Furukawa and Furshpan, 1963). Together these data show that the attenuation of $\Delta A / A$ observed at intervals of 5-30 msec (Fig. 6) demonstrated a powerful shunting effect of the recurrent inhibition.

\section{Optical signals associated with double AD spikes}

The $\mathrm{Ca}^{2+}$ response elicited by double AD shocks with intervals of $>50 \mathrm{msec}$ (Fig. 6) exhibited no sign of inhibition. A similar $\Delta A / A$ was observed with double shocks for intervals ranging from 5 to $500 \mathrm{msec}$ with blocking of the recurrent inhibition (Fig. $7 A, B)$. Despite this lack of inhibition, the $\Delta A / A$ was nonetheless only $\sim 65 \%$ of the control responses to a single shock. This is

decay time constant ( $\tau=4.2 \pm 0.3 \mathrm{sec} ; 11$ responses) might reflect $\mathrm{Ca}^{2+}$ influx through NMDA-type glutamate receptors (Pereda and Faber, 1996). $B$, Superimposed traces of the $\mathrm{Ca}^{2+}$ response evoked in the contralateral M-cell by pairing the two stimuli at intervals denoted below. The $\mathrm{Ca}^{2+}$ response was diminished when the intervals ranged from 2 to $10 \mathrm{msec}$ and gradually recovered with longer intervals. Note that peak amplitudes of $\mathrm{Ca}^{2+}$ response obtained at intervals of $<2 \mathrm{msec}$ were the same as the test response $(A D \times 1)$. Shaded circles indicate the peak amplitude of each $\mathrm{Ca}^{2+}$ response. $C$, Relationship between $\Delta A / A$ ( $y$-axis) and intervals of the paired stimuli ( $x$-axis), summarized from six fish. $\Delta A / A$ values at intervals of $2-30 \mathrm{msec}$ were significantly reduced from control $(* * * * p<0.0001$; **p $<0.003, t$ test). The dotted line expresses the Boltzmann fit to the data points from 2 to $100 \mathrm{msec}$. The half-recovery time was $27.6 \pm 2.5 \mathrm{msec}(n=$ 6). The larger shunt of the $\mathrm{Ca}^{2+}$ response indicates the reciprocal inhibition produced by ipsilateral M-cell firing that was superposed on the commissural feedforward effect (Fig. 9). $D$, Use-dependent depression of reciprocal inhibition. An AD test response evoked $5 \mathrm{msec}$ after the second pulse of the paired conditioning pulse with interpulse intervals $(\Delta t)$ is denoted. Horizontal bars indicate the peak amplitude of the test AD response without a shunt. The inhibitory shunt was clearly reduced at a 100 msec interval. $E$, Relationship between $\Delta A / A$ ( $y$-axis) and intervals of the double conditioning stimuli ( $x$-axis), summarized from seven fish, suggesting that the reciprocal inhibition followed after $200 \mathrm{msec}$ interstimulus intervals but not after short intervals of $100 \mathrm{msec}$. 
probably attributable to the relatively high $\mathrm{Ca}^{2+}$ affinity of the CGD (O'Malley et al., 1999) rather than a real decrease in $\mathrm{Ca}^{2+}$ influx for the full-sized second spike. A similarly diminished increase $(\sim 60 \%)$ in the optical signal of CGD was reported for the response evoked by double stimulation of the parallel fibers on cerebellar Purkinje cells (Kreitzer et al., 2000; Kreitzer and Regehr, 2001). This did not occur when the low-affinity calcium indicator fluo- 4 dextran was used. Thus, the $\Delta A / A$ of the M-cell suggests that a full-sized AD spike was evoked by the second AD stimulus at intervals of $>50 \mathrm{msec}$.

\section{Functions of the local inhibitory network of the M-cell}

During early development in mammals, glycinergic or GABAergic synapses can often function as excitatory inputs, even triggering action potentials (Cherubini et al., 1991). However, at least at the developmental stages we used in the present study, glycinergic inputs to M-cells in zebrafish larvae are unlikely to exert an excitatory effect on the postsynaptic neuron sufficient to trigger action potential firing for the following reasons. First, no excitatory $\mathrm{Ca}^{2+}$ response was induced in the contralateral M-cell by eighth nerve input or via reciprocal inhibitory input (Fig. $10 A$ ). Second, the blockade of the recurrent pathway increased, rather than decreased, the $\Delta A / A$ for intervals of $<40 \mathrm{msec}$ (Fig. 7). Third, no repetitive firing of the $\mathrm{M}$-cell has been observed in field potential recordings in larvae of $>4 \mathrm{dpf}$ (Eaton and Farley, 1975).

Furthermore, our observations suggest that the recurrent inhibitory network onto the M-cell is fully functional by $4 \mathrm{dpf}$. First, there was no developmental change in the recurrent inhibitory shunt of the $\mathrm{Ca}^{2+}$ response between 4 and $8 \mathrm{dpf}$ (Table 1). Second, the kinetics of recurrent IPSCs in larval M-cells (Fig. 8) was similar to that reported in adult fish (Hatta and Korn, 1998). In addition, because the same group of T-reticular neurons are involved in both reciprocal and recurrent pathways (Kimmel et al., 1985), the similar frequency susceptibility of the reciprocal inhibitory shunt (Fig. 10) suggests that the M-cell output synapses of the larva have physiological characteristics similar to those of adult fish (Waldeck et al., 2000). Thus, the recurrent and probably also reciprocal inhibitory networks on the M-cell develop during the first $4 \mathrm{~d}$ after fertilization.

Inhibitory synaptic plasticity was first described in the M-cell and was linked to behavioral conditioning (Korn et al., 1992; Oda et al., 1995). In the adult goldfish, use-dependent changes in inhibition have been shown to underlie the sound conditioning of escape behavior (Oda et al., 1998). The present noninvasive approach provides the possibility of studying this phenomenon in the intact animal. In addition, the use of zebrafish opens the possibility of analyzing disruptions of plasticity or circuitry development in mutants as well as genetic perturbations of plasticity in transgenic lines (Haffter et al., 1996; Lorent et al., 2001).

\section{REFERENCES}

Callaway JC, Lasser-Ross N, Ross WN (1995) IPSPs strongly inhibit climbing fiber-activated $\left[\mathrm{Ca}^{2+}\right]_{\mathrm{i}}$ increases in the dendrites of cerebellar Purkinje neurons. J Neurosci 15:2777-2787.

Cherubini E, Gaiarsa JL, Ben-Ari Y (1991) GABA: an excitatory transmitter in early postnatal life. Trends Neurosci 14:515-519.

Day JW, Hall DH, Hall LM, Bennett MV (1983) $\alpha$-Bungarotoxin labeling and acetylcholinesterase localization at the Mauthner fiber giant synapse in the hatchetfish. J Neurosci 3:272-279.

Di Prisco GV, Pearlstein E, Robitaille R, Dubuc R (1997) Role of sensory-evoked NMDA plateau potentials in the initiation of locomotion. Science 278:1122-1125.
Drapeau P, Ali DW, Buss RR, Saint-Amant L (1999) In vivo recording from identifiable neurons of the locomotor network in the developing zebrafish. J Neurosci Methods 88:1-13.

Eaton RC, Farley RD (1975) Mauthner neuron field potential in newly hatched larvae of the zebrafish. J Neurophysiol 38:502-512.

Eaton RC, Kimmel CB (1980) Directional sensitivity of the Mauthner cell system to vibrational stimulation in zebrafish larvae. J Comp Physiol [A] 140:337-342.

Eaton RC, Lavender WA, Wieland CM (1981) Identification of Mauthner-initiated response patterns in goldfish: evidence from simultaneous cinematography and electrophysiology. J Comp Physiol [A] 144:521-531.

Faber DS, Korn H (1978) Electrophysiology of the Mauthner cell: basic properties, synaptic mechanisms, and associated networks. In: Neurobiology of the Mauthner cell (Faber DS, Korn H, eds), pp 47-131. New York: Raven.

Faber DS, Korn H (1982) Transmission at a central inhibitory synapse. I. Magnitude of unitary postsynaptic conductance change and kinetics of channel activation. J Neurophysiol 48:654-678.

Fetcho JR, O'Malley DM (1995) Visualization of active neural circuitry in the spinal cord of intact zebrafish. J Neurophysiol 73:399-406.

Fetcho JR, O'Malley DM (1997) Imaging neuronal networks in behaving animals. Curr Opin Neurobiol 7:832-838.

Fox AP, Nowycky MC, Tsien RW (1987) Single-channel recordings of three types of calcium channels in chick sensory neurones. J Physiol (Lond) 394:173-200.

Furukawa T, Furshpan EJ (1963) Two inhibitory mechanisms in the Mauthner neurons of goldfish. J Neurophysiol 26:140-176.

Furukawa T, Fukami Y, Asada Y (1964) Effects of strychnine and procaine on collateral inhibition of the Mauthner cell of goldfish. Jpn J Physiol 14:386-399.

Haffter P, Granato M, Brand M, Mullins MC, Hammerschmidt M, Kane DA, Odenthal J, van Eeden FJ, Jiang YJ, Heisenberg CP, Kelsh RN, Furutani-Seiki M, Vogelsang E, Beuchle D, Schach U, Fabian C, Nusslein-Volhard C (1996) The identification of genes with unique and essential functions in the development of the zebrafish, Danio rerio. Development 123:1-36.

Hatta K, Korn H (1998) Physiological properties of the Mauthner system in the adult zebrafish. J Comp Neurol 395:493-509.

Hatta K, Korn H (1999) Tonic inhibition alternates in paired neurons that set direction of fish escape reaction. Proc Natl Acad Sci USA 96:12090-12095.

Kimmel CB, Powell SL, Metcalfe WK (1982) Brain neurons which project to the spinal cord in young larvae of the zebrafish. J Comp Neurol 205:112-127.

Kimmel CB, Metcalfe WK, Schabtach E (1985) T reticular interneurons: a class of serially repeating cells in the zebrafish hindbrain. J Comp Neurol 233:365-376.

Korn H, Oda Y, Faber DS (1992) Long-term potentiation of inhibitory circuits and synapses in the central nervous system. Proc Natl Acad Sci USA 89:440-443.

Kreitzer AC, Regehr WG (2001) Retrograde inhibition of presynaptic calcium influx by endogenous cannabinoids at excitatory synapses onto Purkinje cells. Neuron 29:717-727.

Kreitzer AC, Gee KR, Archer EA, Regehr WG (2000) Monitoring presynaptic calcium dynamics in projection fibers by in vivo loading of a novel calcium indicator. Neuron 27:25-32.

Liu KS, Fetcho JR (1999) Laser ablations reveal functional relationships of segmental hindbrain neurons in zebrafish. Neuron 23:325-335.

Lorent K, Liu KS, Fetcho JR, Granato M (2001) The zebrafish space cadet gene controls axonal pathfinding of neurons that modulate fast turning movements. Development 128:2131-2142.

McPherson DR, McClellan AD, O’Donovan MJ (1997) Optical imaging of neuronal activity in tissue labeled by retrograde transport of calcium green dextran. Brain Res Brain Res Protoc 1:157-164.

Oda Y, Charpier S, Murayama Y, Suma C, Korn H (1995) Long-term potentiation of glycinergic inhibitory synaptic transmission. J Neurophysiol 74:1056-1074.

Oda Y, Kawasaki K, Morita M, Korn H, Matsui H (1998) Inhibitory long-term potentiation underlies auditory conditioning of goldfish escape behaviour. Nature 394:182-185.

O'Malley DM, Kao YH, Fetcho JR (1996) Imaging the functional organization of zebrafish hindbrain segments during escape behaviors. Neuron 17:1145-1155.

O’Malley DM, Burbach BJ, Adams PR (1999) Fluorescent calcium indicators: subcellular behavior and use in confocal imaging. Methods Mol Biol 122:261-303.

Pereda AE, Faber DS (1996) Activity-dependent short-term enhancement of intercellular coupling. J Neurosci 16:983-992.

Sabatini BL, Regehr WG (1995) Detecting changes in calcium influx which contribute to synaptic modulation in mammalian brain slice. Neuropharmacology 34:1453-1467. 
Santalova IM, Moshkov DA (1999) Smooth endoplasmic reticulum in fish Mauthner cells at different functional states. Neuroscience 89:593-602.

Svoboda K, Denk W, Kleinfeld D, Tank DW (1997) In vivo dendritic calcium dynamics in neocortical pyramidal neurons. Nature 385:161-165.

Triller A, Korn H (1981) Morphologically distinct classes of inhibitory synapses arise from the same neurons: ultrastructural identification from crossed vestibular interneurons intracellularly stained with HRP. J Comp Neurol 203:131-155.

Tsien RY (1988) Fluorescence measurement and photochemical manipulation of cytosolic free calcium. Trends Neurosci 11:419-424.

Waldeck RF, Pereda A, Faber DS (2000) Properties and plasticity of paired-pulse depression at a central synapse. J Neurosci 20:5312-5320. Westerfield M (1995) The zebrafish book: a guide for the laboratory use of zebrafish (Brachydanio rerio). Eugene, OR: University of Oregon.

Windhorst U (1996) On the role of recurrent inhibitory feedback in motor control. Prog Neurobiol 49:517-587.

Zottoli SJ (1977) Correlation of the startle reflex and Mauthner cell auditory responses in unrestrained goldfish. J Exp Biol 66:243-254.

Zottoli SJ, Faber DS (1980) An identifiable class of statoacoustic interneurons with bilateral projections in the goldfish medulla. Neuroscience 5:1287-1302.

Zottoli SJ, Newman BC, Rieff HI, Winters DC (1999) Decrease in occurrence of fast startle responses after selective Mauthner cell ablation in goldfish (Carassius auratus). J Comp Physiol [A] 184:207-218. 